\section{Industry 4.0 technologies usage: motives and enablers}

Industry 4.0 technologies usage

\author{
Tomaž Čater
}

Department of Management and Organization, School of Economics and Business, University of Ljubljana, Ljubljana, Slovenia, and

Barbara Čater, Matej Černe, Matjaž Koman and Tjaša Redek

School of Economics and Business, University of Ljubljana, Ljubljana, Slovenia

\begin{abstract}
Purpose - The paper aims to contribute to a better understanding of the drivers for the use of Industry 4.0 technologies by investigating (1) what motivates companies to consider using I4 technologies and (2) what enables (or hinders) the intention to use I4 technologies to translate into their actual use.

Design/methodology/approach - The study uses survey data collected from a sample of export-oriented manufacturing companies with more than 10 employees. Final analysis is conducted on 124 companies.

Findings - The results show that companies are proactively approaching I4. Only efficiency motives and expected competitive advantage have a positive effect on the intention to use I4 technologies, which in turn positively influences their actual use. The external, legitimacy-based, motives do not play a significant role in explaining the intention to use. With respect to I4 technology enablers, employee competency positively moderates and availability of finance negatively moderates the relationship between intention to use and actual use.

Research limitations/implications - The work extends the existing knowledge base on I4 technology drivers in companies that are not major global trendsetters but are heavily embedded in the value chains of companies from the most industrially developed economies. The study is limited to manufacturing companies in a small European economy and should be retested in other contexts.

Practical implications - The study can help managers implement I4 technologies in their companies more successfully.

Originality/value - We take a novel research approach by proposing a framework that clearly distinguishes between motives and enablers for the use of I4 technologies.
\end{abstract}

Keywords Industry 4.0, Technology, Actual use, Intention to use, Enablers, Motives

Paper type Research paper

\section{Introduction}

The fourth industrial revolution known as Industry 4.0 (I4) brought about many new technologies in the field of business process digitalization (Ghobakhloo, 2018). The major advantages of introducing new technologies are increasing productivity and resource savings, process transparency, more profitable business models, higher quality and improved workplace conditions (Müller et al, 2018b; Staufen, 2018; Nosalska et al., 2019). Closely linking products and machines increases efficiency, reduces costs and saves resources. Intelligent surveillance and transparent procedures provide businesses with a constant overview of the business process, which enables them to respond quickly and with flexibility to changes in the market. Intelligent products and machines collect various data that help develop new products and services and enable optimization of production processes (Brettel et al, 2014).

(C) Tomaž Čater, Barbara Čater, Matej Černe, Matjaž Koman and Tjaša Redek. Published by Emerald Publishing Limited. This article is published under the Creative Commons Attribution (CC BY 4.0) licence. Anyone may reproduce, distribute, translate and create derivative works of this article (for both commercial and non-commercial purposes), subject to full attribution to the original publication and authors. The full terms of this licence may be seen at http://creativecommons.org/licences/by/4.0/legalcode

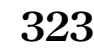
Revised 24 April 2021 14 June 2021

Accepted 23 June 2021

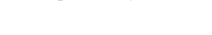

A
Received 21 January 2021 
JMTM 32,9

324

Despite these advantages, it is still unclear what will be the impact of I4 on companies (Hermann et al., 2019). There are many challenges, including issues related to information technology security and data protection, the organization of work, lack of skills, training of skilled workers and the development of uniform standards required in the digitized economy (Stanton Chase, 2017).

The awareness that I4 technologies' adoption and use not only brings forth advantages but also challenges (Johansson et al., 2019; Szalavetz, 2019; Zheng et al., 2019) poses a number of questions of which one of the most important is "What drives I4 technologies' usage?". While integrating and using a disruptive technology early can provide a small company with an opportunity to compete with larger competitors, the adoption of a poor-fitting technology may not lead to the subsequent use of such technology and is likely to leave the company at a competitive disadvantage (Tellis, 2006). Given the risk/reward trade-off inherent in new technology adoption, the need to correctly understand the drivers of adoption and use is evident (Obal, 2017). With the purpose of contributing to a better understanding of these drivers, this study aims to investigate (1) what motivates companies to consider the use of I4 technologies and (2) what enables/hinders (but not motivates) the intention to use I4 technologies to translate into their actual use.

The first intended contribution of this paper to the literature is therefore in conceptualizing and testing the research framework that clearly distinguishes between the motives and enablers of I4 technology usage. While internal and external motives help us understand why companies would use I4 technologies, sufficient finance, knowledgeable people, etc. do not motivate the use of I4 technologies but rather enable it. Although the literature already addresses the issue of the lack of enabling factors (or the existence of obstacles) that may hinder the use of new technologies (Neto et al., 2017), these enablers have not yet been conceptualized as moderators in a structural model. This is important as such a perspective enables us to capture boundary conditions for transforming intentions into actual use, thereby providing researchers and managers with a more comprehensive framework of complex interactions between relevant variables leading to the actual use of technology.

Second, in delineating among motives and enablers and specifying their different roles in the model, our paper draws on different theoretical approaches and aims to contribute to developing a more cohesive and consistent theory in the field. More specifically, by combining the motivation perspective that builds on the transaction cost theory and institutional theory (Roberts and Greenwood, 1997; Grewal et al., 2001; Son and Benbasat, 2007), the technology acceptance model (Davis, 1986; Davis et al., 1989), the unified theory of the acceptance and use of technology (Venkatesh et al., 2003) and the resource/capabilitybased view (Barney, 1991; Winter, 2003), our paper intends to add to the development of an overarching theoretical framework in the field of I4 technologies usage.

Finally, a number of studies have been carried out on the topic of I4 in developed economies, which are considered to be the leaders of the global economy (a more detailed review is provided in Liao et al. (2017), Piccarozzi et al. (2018), Mariani and Borghi (2019). On the other hand, much less is known about the progress of I4 in countries that are considered to be the followers of global development (Cater et al., 2019). By setting our study in an open European economy, the third intended contribution of this paper is to add to the knowledge base on the drivers of I4 technologies in companies which are (more often than not) technological followers, strongly embedded in the global value chains of companies from the most industrially developed economies.

\section{Theoretical background and hypotheses development}

\subsection{Industry 4.0 technologies}

Industry 4.0 denotes a paradigm that makes an organization "smart" by applying advanced information and communication systems and future-oriented technologies (Sanders et al., 2016). 
The focus of I4 is on digital-technology-based solutions, which change the way companies create value (Oesterreich and Teuteberg, 2016), and the extensive interconnection of the physical and virtual worlds (Veile et al., 2020). While the emphasis on new technologies means the I4 paradigm is strongly techno-centric (Cimini et al., 2021), its interconnecting character suggests the full potential of I4 can only be leveraged across value chains of multiple organizations and not in the isolated environment of a single organization (Müller et al., 2018; Veile et al., 2019). Büchi et al. (2020) propose that a company's openness to Industry 4.0 can be measured in terms of breadth (the number of technologies adopted by the company) and depth (the number of stages in the company's value chain in which these technologies are implemented).

Compared to more traditional and simple digital technologies (electronic data interchange, administrative software packages, etc.), I4 technologies are significantly more complex, knowledge-intensive and heavily integrated into organizations' core processes (Kamble et al., 2018). In addition, their common characteristics are the use of wireless networks, assistance in decision-making and interconnections between individual technologies (Dos Santos et al., 2021). Frequently discussed I4 technologies in the literature (e.g. Posada et al., 2015; Ghobakhloo and Ching, 2019; Bosman et al., 2020; Büchi et al., 2020; Dos Santos et al., 2021) include additive manufacturing, artificial intelligence, augmented/virtual reality, (industrial) automation, big data, cloud computing/storage, cyber physical systems, cybersecurity, enterprise resource planning, industrial Internet, Internet of things and intelligent/autonomous robotics.

While most of the literature does not differentiate between levels of I4 technologies, Ghobakhloo and Ching (2019) distinguish between second-tier (cyber physical systems, Internet of things) and first-tier (all other) technologies. Although first-tier technologies need to interact with each other to deliver their full functionalities, they can still operate independently. In contrast, second-tier technologies are not "off-the-shelf products" because their use relies on the implementation of various combinations of first-tier technologies (Ghobakhloo and Ching, 2019). Similarly, Frank et al. (2019) divide I4 technologies into two distinct layers according to their main objective. The front-end technologies (smart manufacturing, smart products, smart supply chain, smart working) deal with operational and market needs and have an end-application purpose for the companies' value chain. The base technologies (Internet of things, cloud, big data and analytics) include technologies that provide connectivity and intelligence for front-end technologies.

\subsection{The overarching theoretical approach behind the hypothesized model}

Our paper follows the overarching theoretical approach whereby connections are achieved through a set of overarching ideas that comprise the model. The model can therefore be viewed as a combination of previously developed theoretical approaches (Cumming, 2014). In conceptualizing our hypothesized model, we build on the organizational motivation, resource/ capability-based and technology acceptance literature, as well as their underlying theories, and propose the moderated mediation model depicted in Figure 1. The model's main part investigates the influence of external/reactive (competitor, supplier and customer pressures) and internal/proactive (efficiency and expected competitive advantage) motives on the intention to use I4 technologies, and the latter's influence on the actual use of I4 technologies. On top of these causal links which constitute the mediation model, we inspect the moderation effect of three enabling factors (finance, people and organizational fit) on the link between the intention to use and the actual use of I4 technologies. All links are hypothesized to be positive. The remainder of this section presents the theories we build on and provides detailed arguments for the proposed hypotheses.

\subsection{Motives for using new technologies}

2.3.1 Theoretical background. In conceptualizing the motives for I4 technology usage, we build on the motivation perspective for innovation adoption in organizational markets, which 


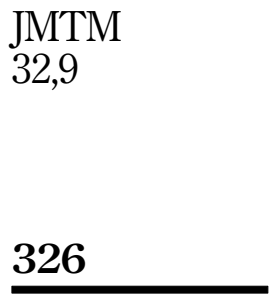

Figure 1.

The hypothesized model and its theoretical background

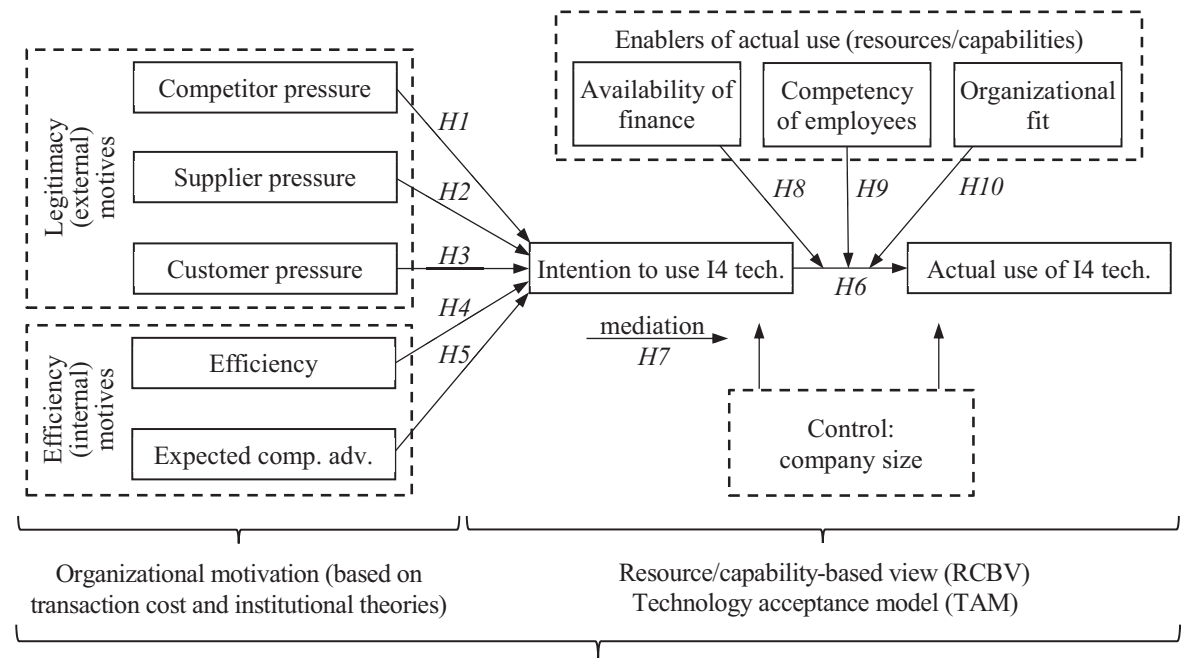

Unified theory of the acceptance and use of technology (UTAUT)

Note(s): All relationships are hypothesized to be positive

uses the transaction cost theory and institutional theory (Roberts and Greenwood, 1997; Grewal et al., 2001; Son and Benbasat, 2007) as the main theoretical background, and propose efficiency and legitimacy as two primary motives for adopting I4 technologies.

Legitimacy as a motive is linked to external market pressure, i.e. the extent to which competitive and industry conditions force participants to pay close attention to each other's strategic decisions, including the use of innovative technologies (Gatignon and Robertson, 1989; Chwelos et al., 2001). Legitimacy can further be divided into mimetic and normative pressures (Son and Benbasat, 2007). Mimetic (competitor) pressures are those caused by uncertainty which makes companies imitate the strategic decisions of leading competitors (Benders et al., 2006). Of course, companies that have traditionally dominated the market may also face pressure as a result of innovative technologies introduced by new competitors (Linz et al., 2017). On the other hand, normative pressures are those that make companies conform to the norms in the industry. These norms are usually under the control of established industry participants, such as suppliers (Benders et al., 2006; Son and Benbasat, 2007; Obal, 2017). In our paper we default to mimetic competitor pressure and normative supplier pressure as two legitimacy-related motives according to Son and Benbasat (2007). However, we also include normative customer pressure as the third legitimacy-related motive for using I4 technologies. The arguments for this inclusion are twofold. First, in line with the politicaleconomic framework (Stern and Reve, 1980) and stakeholder theory (Freeman, 1984), customers can represent a significant external force influencing the companies' strategic behavior (Banerjee et al., 2003). Second, I4 technologies heavily rely on digitalization which typically demands the company's technologies to communicate with the suppliers' and customers' technologies.

Unlike legitimacy, efficiency motives are seen as an internal organizational drive to adopt a new technology (Obal, 2017) and are premised on the rationalistic expectation of enhancing efficiency of organizational processes (Son and Benbasat, 2007). The motivation to enhance company efficiency significantly motivates new technology adoption and the intention to continue with its use (Bhattacherjee and Premkumar, 2004). In addition to efficiency, our 
paper proposes a more strategically-oriented internal driver of new technology usage which we define as the expected competitive advantage. We rationalize our decision based on the propositions of Müller et al. (2018b) and Ghobakhloo (2020) that the implementation of I4 technologies delivers both operational and strategic opportunities. A similar logic to define expected competitive advantage as a motive for companies' strategic decisions was also applied in other studies (e.g. Lee and Green, 1994; Banerjee et al., 2003).

This study therefore discusses five groups of motives for using I4 technologies: competitor pressure, supplier pressure, customer pressure, expected efficiency and expected competitive advantage. While the first three are seen as external motives, the fourth and the fifth can be defined as internal motives (Momani and Jamous, 2017). In addition, competitor, supplier and customer pressure can be treated as primarily reactive motives, whereas efficiency and competitive advantage typically represent proactive motives.

2.3.2 Hypotheses development. A high level of competitive pressure among potential innovation users enhances innovation adoption because it is important for maintaining a good market position in highly competitive markets (Gatignon and Robertson, 1989; Chwelos et al., 2001). Legitimacy-oriented motives, such as mimetic and normative pressures, may lead to more adoptions (Son and Benbasat, 2007; Ghobakhloo and Ching, 2019), but probably do not lead to continued technology usage (Karahanna et al., 1999). It could be that when mimetic and normative pressures are strong, companies' intention to use increases although the adopted technology may not be a perfect fit which can lead to its passive post-adoption usage (Scott, 1987; Grewal et al., 2001). Based on these arguments, our paper does not hypothesize a direct influence of legitimacy-based motives on the actual use but on the intention to use I4 technologies.

H1-H3. Competitor pressure (H1), supplier pressure (H2) and customer pressure (H3) are positively related to the intention to use I4 technologies.

Bharati and Chaudhury (2004) propose that increased efficiency as a result of new technology leads to higher satisfaction of the user. Further, companies with efficiency-oriented motives take greater effort to better understand a product/technology they intend to purchase. Therefore, they are more likely to have realistic expectations about the benefits from its use (Grewal et al., 2001; Rask and Kragh, 2004), which may increase their intention to use the technology (Obal, 2017). With regard to the expected competitive advantage as a motive, several studies (Tsai et al., 2005; Kim et al., 2008, 2009; Ghobakhloo, 2020) also confirmed that new technologies may enable companies to secure competitive advantages. Following the above arguments, we hypothesize that a company's intention to use I4 technologies will increase if the company's motives are linked to the expected improvements in efficiency and competitive advantage.

H4-H5. Expected efficiency (H4) and competitive advantage (H5) are positively related to the intention to use I4 technologies.

\subsection{Intention to use vs actual use}

2.4.1 Theoretical background. With regard to the attitude to and actual use of I4 technologies, our paper builds on theoretical frameworks in the user technology acceptance, among which the most relevant for our study are the technology acceptance model (TAM) (Davis, 1986; Davis et al., 1989) and the unified theory of the acceptance and use of technology (UTAUT) (Venkatesh et al., 2003). The TAM is closely linked to the emergence of informationcommunication technology and builds on the "attitudes - intentions - actual behavior" paradigm. It assumes that attitudes toward new technology influence users' intentions to use the technology, while the intentions to use result in the actual technology usage (Lacka and Chong, 2016). The UTAUT brings motivational factors into the picture, positing that
Industry 4.0 technologies usage 
JMTM 32,9

328

performance expectancy, effort expectancy and social influence affect the behavioral intention to use a technology, while the behavioral intention and facilitating conditions influence the actual use of the technology (Escobar-Rodríguez and Carvajal-Trujillo, 2014).

Both the TAM and UTAUT provide strong theoretical support for our study by clearly distinguishing the intention to use from the actual use of technology. Intentions to use new technology explain its real usage measured in a subsequent period (Davis et al., 1989), therefore providing theoretical support for studying the relationship between the intended and actual use of I4 technologies. Moreover, since the UTAUT also introduces motivational factors (such as performance expectancy and social influence) as antecedents of behavioral intention to use new technology, this also provides theoretical support for studying the motives behind the use of I4 technologies.

2.4.2 Hypotheses development. In the context of new technology usage, the positive link between the intention to use and actual use has mostly been argued by the advocates of the TAM and UTAUT models (Davis, 1986; Escobar-Rodríguez and Carvajal-Trujillo, 2014). Accordingly, vast empirical research (e.g. Davis et al., 1989; Taylor and Todd, 1995; Venkatesh and Davis, 2000; Venkatesh et al., 2000, 2003; 2012; Yi and Hwang, 2003) in the context of new technologies usage confirms this causal link as positive. Building on previous considerations that intentions act as a direct antecedent of actual use this is also the hypothesis we test in our model. Yet, based on the outlined assumptions of the TAM and especially the UTAUT theories, we additionally test the mediation hypothesis that motives indirectly affect actual use via intentions.

H6. The intention to use I4 technologies is positively related to the actual use of I4 technologies.

H7. The intention to use I4 technologies mediates the effect of motives on the actual use of I4 technologies.

\subsection{Enablers of actual use}

2.5.1 Theoretical background. The hypothesized positive relationship of the intention to use with actual use is both theoretically and empirically well supported. However, we cannot ignore the boundary conditions that may influence this relationship. According to Palmatier (2016), direct effect links that may turn out unrealistic if they ignore boundary conditions call for the inclusion of managerially controllable moderators in the model. In our case, the boundary conditions can be linked to different obstacles that may prevent the intention to use resulting in actual use. Neto et al. (2017) discuss several obstacles to the actual implementation of new technologies, namely cultural (related to the lack of intellectual capacity of employees and owners/managers), financial (related to financing new technology purchases), technical (resulting among other things from low-skilled labor), organizational and governmental (e.g. excessive tax burdens).

Theoretical support for the above conceptualization of boundary conditions in our model can be found in the resource/capability-based view (RCBV). The RCBV suggests that, in order to gain competitive advantage, firms need internal resources and capabilities that allow them to operate their chosen lines of business efficiently and effectively (Barney, 1991; Winter, 2003). Resources and capabilities therefore act as enablers (internal boundary conditions) that facilitate organizations to obtain beneficial outcomes and competitive advantage (Liu et al., 2009; Park and Lee, 2011). By arguing that companies need resources/capabilities to be able to transform their strategic intentions into actual performance in the market (Bieńkowska and Tworek, 2021), the RCBV can be used to turn the logic of the obstacles to I4 technology usage (Neto et al., 2017) upside down and assume that nonexistent obstacles may act as enablers of the actual use of I4 technologies. Hence, sufficient finance, knowledgeable people, etc. are not 
motives that positively influence the intention to use, but are resources/capabilities that act as firm-level boundary conditions (moderation factors) which facilitate the intended use to result in actual use.

A similar logic can also be found in the UTAUT model, which assumes that not only behavioral intention but also facilitating conditions influence the actual use of technology (Escobar-Rodríguez and Carvajal-Trujillo, 2014). Based on the above logic of moderation effects and the literature (e.g. Neto et al., 2017) on the obstacles to or enablers of new technology usage, this paper discusses the moderation effect of three enabling factors (resources and capabilities). These are availability of finance, competency of employees and organizational fit. The following paragraphs summarize past research on the effects of these three enabling factors on new technology usage.

2.5.2 Hypotheses development. As found by Davila et al. (2003), companies with available finance are more likely to use new technology than financially weaker companies. This may be because financially sound companies perceive the same level of investment as a smaller sacrifice. Further, the availability of finance enables companies to better withstand negative consequences if the technology adoption fails (Gao et al., 2012). Several other authors also argue that difficulties in accessing adequate financing (Gombault and Versteege, 1999) and consequently the lack of investment capital (Silvestre and Silva Neto, 2014) are the main barriers to using new technologies in SMEs.

With regard to the competency of employees, studies claiming a positive association between the prevalence of technical specialists within a company and receptivity to innovation (Gatignon and Robertson, 1989) emerged decades ago. Similarly, more contemporary studies also confirm that employees must be properly qualified to be able to use new technologies (Erol et al., 2016; Veile et al., 2019), which was also reported in the context of I4 technologies in manufacturing companies (Bauer et al., 2015). Employees as technology users are therefore critical success factors (Müller et al., 2018b) and their lack of competency is identified as the main obstacle to I4 implementation (Stanton Chase, 2017).

Finally, if the adoption of a new technology is not tailored to a company's organizational specifics, synchronization with the existing equipment, structures and processes can become complex and costly. This may be particularly challenging for smaller companies (Müller et al., 2018a; Pirola et al., 2019). Several other studies (Chau and Tam, 1997; Ramdani et al., 2009; Ghobakhloo and Ching, 2019) have also shown the relevance of organizational fit for the implementation of new technologies.

The above discussion leads us to propose the following three hypotheses:

H8-H1O. Availability of finance (H8), competency of employees (H9) and organizational fit (H10) positively moderate the relationship between the intention to use I4 technologies and their actual use.

\section{Methodology}

Variables for our model were operationalized based on operationalizations used in past research, with some adaptations. Scales for reactive motives (competitor pressures, supplier pressures, customer pressures) were based on Obal's (2017) scales for mimetic competitor pressures and normative pressures. As for proactive motives, efficiency was measured with statements based on Obal's (2017) scale for efficiency motives, while to measure expected competitive advantage we adapted the scale from Banerjee et al. (2003). With regard to the moderators, we measured the availability of finance with a scale created based on the findings of Neto et al. (2017). Organizational fit was measured with the scale of Müller et al. (2018b), whereas for the competencies of employees we used adapted statements for Obal's (2017) IT capabilities. Each statement was evaluated on a scale from 1 to 7 , where 1 stands for 
JMTM 32,9

"strongly disagree" and 7 for "strongly agree". In measuring the use of I4 technologies, our decision was similar to Büchi et al.'s (2020) idea of I4's depth and was based on Rachinger et al.'s (2019) observation that digitalization has influenced various business activities. Building on Rachinger et al.'s (2019) findings that the influence of digitalization on business model elements and the potential for optimization depends importantly on the company's industry, we decided to focus on the depth instead of the breadth in the use of I4 technologies. By so doing, we seek to balance the differences among various manufacturing industries. We initially listed the most commonly discussed I4 technologies in the literature (Posada et al., 2015; Büchi et al., 2020) (e.g. augmented/virtual reality, (industrial) automation, big data, cloud computing/storage, cyber physical systems, Internet of things, intelligent/autonomous robotics, 3D printing) and asked respondents in which areas of the value chain (nine business areas of the value chain were provided: planning and control, research and development, purchasing, logistics, production, marketing and sales, finance and accounting, HRM and communication) they have used several of these technologies. We applied a series of dummy variables coded as 0 where I4 technologies are not used or rarely used in the specific area of the value chain, and 1 if they are used frequently. These nine dummies were summed to obtain an indicator of actual use, ranging from 0 (when technologies have not been implemented) to 9 (when technologies have been used in all areas). After we checked the content validity, we adjusted the scales and tested the questionnaire on 10 companies.

Slovenian export-oriented manufacturing companies with more than 10 employees were defined as a population for this study. Slovenia is a small open European economy that is very export oriented. Its companies are strongly embedded in the value chains of companies from the most industrially developed economies. Therefore, it represents an interesting context to test results of the studies from the more developed economies. The sampling frame was developed from the Database of Slovenian Exporters (SloExport). Before starting with the data collection, companies were contacted by telephone to identify the most relevant respondent in the company (a person responsible for introducing new technologies or having the best overview of this topic). Upon obtaining their e-mail address, we asked for their consent to participate in the web-based survey. The target population was manufacturing due to the relevance and general intensity of use of new technology in this area. Due to the rationality of implementing new technologies and the ability to use them, the target population was companies with at least ten employees. Out of the population of 1,442 companies (the total number of manufacturing export-oriented companies in Slovenia with more than ten employees), we received the consent of 1,082 companies and 124 companies finished the survey. The demographics of our final sample are summarized in Table 1. Regarding the depth of I4 technologies use, the mode was 0 (19.4\%), the median was 4 and the mean was 3.9 business areas. I4 technologies were most often used in finance and accounting (60.5\%), planning and control (56.5\%) and production (50.8\%).

Before conducting the analysis of the measurement and structural model, we conducted an analysis of missing values (Little's MCAR test, using IBM SPSS 25), which indicated that missing values are missing completely at random. Therefore, we proceeded with the analysis.

\section{Results}

\subsection{Measurement model}

We tested the properties of the proposed research constructs with structural equation modeling (SEM). First, we performed a confirmatory factor analysis (CFA) to test the measurement model. The analysis was performed using Mplus version 7.3. Although we had used some previously validated scales, certain items turned out problematic, presumably due to translation or cultural differences. Therefore, we discarded the problematic items for each construct one by one based on low loadings on the designated construct. Table 2 shows the 


\begin{tabular}{|c|c|c|c|}
\hline Criterion & Group & $\begin{array}{c}\text { Share } \\
(\%)\end{array}$ & $\begin{array}{l}\text { Industry } 4.0 \\
\text { technologies }\end{array}$ \\
\hline \multirow[t]{3}{*}{ Company's size } & Small companies & 54.7 & \\
\hline & Medium-sized companies & 23.9 & \\
\hline & Large companies & 21.4 & \\
\hline \multirow{4}{*}{$\begin{array}{l}\text { Company's position in the } \\
\text { value chain }\end{array}$} & Producers of end-products & 45.0 & \\
\hline & $\begin{array}{l}\text { Suppliers of semi-finished products or components for end } \\
\text { products }\end{array}$ & 44.2 & 331 \\
\hline & $\begin{array}{l}\text { Producers of machinery used by other companies in their } \\
\text { production }\end{array}$ & 7.5 & \\
\hline & Suppliers of basic (raw) materials & 3.3 & \\
\hline \multirow{4}{*}{$\begin{array}{l}\text { Company's digitalization } \\
\text { level }\end{array}$} & Digital novices (beginners in digitalization) & 38.7 & \\
\hline & $\begin{array}{l}\text { Digital integrators (partly digitalized processes; using I4 } \\
\text { technologies only internally) }\end{array}$ & 47.8 & \\
\hline & $\begin{array}{l}\text { Horizontal collaborators (many digitalized processes; also using I4 } \\
\text { technologies to cooperate with partners in the value chain) }\end{array}$ & 11.7 & \\
\hline & Digital champions (heavily digitalized processes) & 1.8 & \\
\hline \multirow{5}{*}{$\begin{array}{l}\text { Respondent's* position in } \\
\text { the company }\end{array}$} & Members of management or department directors & 32.5 & \\
\hline & Directors (or chairpersons of the management board) & 16.2 & \\
\hline & Deputy directors (or members of the management board) & 12.0 & \\
\hline & Persons responsible for introducing new technologies & 12.0 & \\
\hline & Other (mostly middle-management) positions & 27.3 & \\
\hline \multicolumn{3}{|c|}{$\begin{array}{l}\text { Note(s): *On average, the respondents had } 19.4 \text { years (standard deviation } 10.27 \text { ) of working experience, of } \\
\text { those } 12.7 \text { years (standard deviation 9.41) in the current company }\end{array}$} & Demographics o \\
\hline
\end{tabular}

retained measurement variables and the proposed constructs. Overall, the fit of the measurement model $\left(\chi^{2}=453.63, \mathrm{df}=189, p<0.01, \chi^{2} / \mathrm{df}=2.40\right.$; RMSEA $=0.09,90 \% \mathrm{CI}$ is $0.08-0.10 ; \mathrm{SRMR}=0.068 ; \mathrm{CFI}=0.92$; TLI $=0.90$ ) is acceptable (Schermelleh-Engel et al., 2003).

Results of the reliability analysis are presented in Table 2 . All values for composite reliability are above the required 0.70 . According to a complementary measure for construct reliability - the average variance extracted (AVE) all constructs have acceptable reliability (Fornell and Larcker, 1981).

The model was also tested for convergent and discriminant validity. In line with Anderson and Gerbing (1988), all $t$-values of the loadings of the measurement variables on the respective latent variables are statistically significant. Thus, convergent validity is supported. Discriminant validity was assessed with the approach proposed by Fornell and Larcker (1981). For all pairs of latent variables, values of AVE were greater than the square of correlation between the latent variables, thus supporting discriminant validity (Table 3). Reliability and validity for moderators (availability of finance (Cronbach $\alpha=0.90$ ), competency of employees (Cronbach $\alpha=0.94$ ) and organizational fit (Cronbach $\alpha=0.89$ )) that are going to be used in the second stage of hypotheses testing were established in a similar manner.

Because all variables in our research are based on same-source data, common method bias is a potential issue. We attempted to reduce the causes for common method bias at the response reporting stage using some procedural remedies suggested by Podsakoff et al. (2012). We allowed the respondents' answers to be anonymous and asked them to answer questions as honestly as possible. Further, we did not reveal the conceptual framework of our study and mixed the constructs in a way that reduced the respondents' possibility to guess how the researchers wanted them to respond. We also controlled for CMB with statistical remedies using the marker variable test suggested by Lindell and Whitney (2001). We used 
Competitor pressure (EX, $\alpha=0.91, C R=0.92, A V E=0.78$ )

We consider using I4 technologies because our key competitors are using them $\quad 0.77$

$\begin{array}{ll}\text { Our competitors that use I4 technologies benefited greatly } & 0.93\end{array}$

Our competitors that use I4 technologies are perceived favorably by others in our industry $\quad 0.94$

332 Supplier pressure ( $E X, \alpha=0.92$; $C R=0.91, A V E=0.77$ )

We feel pressured to adopt I4 technologies by our suppliers

Large pressure is placed on our firm by our suppliers to use I4 technologies

We consider using I4 technologies because several industry sources, including our suppliers, promote them

Customer pressure (EX, $\alpha=0.92, C R=0.91, A V E=0.78$ )

We feel pressured to adopt I4 technologies by our buyers

Large pressure is placed on our firm by our buyers to use I4 technologies

We consider using I4 technologies because several industry sources, including our buyers, promote them

Efficiency (EX, $\alpha=0.89, C R=0.89, A V E=0.66)$

We consider using I4 technologies because we think it would increase our efficiency

We consider using I4 technologies because we expect it to reduce the costs of running our business

We consider using I4 technologies because we think it would streamline our operations

We consider using I4 technologies because we believe it would reduce the cost of transacting business with our exchange partners

Expected competitive advantage ( $E X, \alpha=0.91, C R=0.89, A V E=0.66$ )

We expect the use of I4 technologies will lead to substantial cost advantages for our firm

By regularly investing in new I4 technologies our firm can be a leader in the market

Our firm can enter lucrative new markets by using I4 technologies

Our firm will increase market share by using I4 technologies

Intentions to use ( $E D, \alpha=0.96, C R=0.96, A V E=0.8$ )

We consider (further) utilizing I4 technologies in the future

We are in favor of (further) using I4 technologies in our firm

We are willing to (further) implement I4 technologies in the future

We intend to (further) digitalize business processes in our firm

Actual use (ED, sum of use-areas)

Moderators used in the PROCESS model

Availability of finance (MO; $\alpha=0.90)$

Our company faces problems investing in I4 technologies due to the absence of enough own investment capital $(R)$

Our company faces problems investing in I4 technologies due to difficult access to adequate external financing $(R)$

Our company faces problems investing in I4 technologies due to the high cost of investment capital (R)

Competency of employees ( $M O ; \alpha=0.94$ )

Our firm has employees with strong professional knowledge in the area of I4 technologies

Our firm has strong technical support staff in the area of I4 technologies

Our employees have relevant capabilities to work in the I4 environment

Our employees are competent to work in the I4 environment

Organizational fit (MO; $\alpha=0.89)$

For us, implementing Industry 4.0 is not reasonable $(R)$

Customer demands are too individualized to implement Industry $4.0(R)$

We have too little standardization to implement Industry $4.0(R)$

Table 2.

Measurement model
Note(s): $\mathrm{SFL}=$ standardized factor loading; $\mathrm{EX}=$ exogenous construct; $\mathrm{ED}=$ endogenous construct; $\mathrm{MO}=$ moderator $R=$ reverse-coded item; $\alpha=$ Cronbach Alpha; $\mathrm{CR}=$ Composite Reliability; $\mathrm{AVE}=$ Average Variance Extracted 


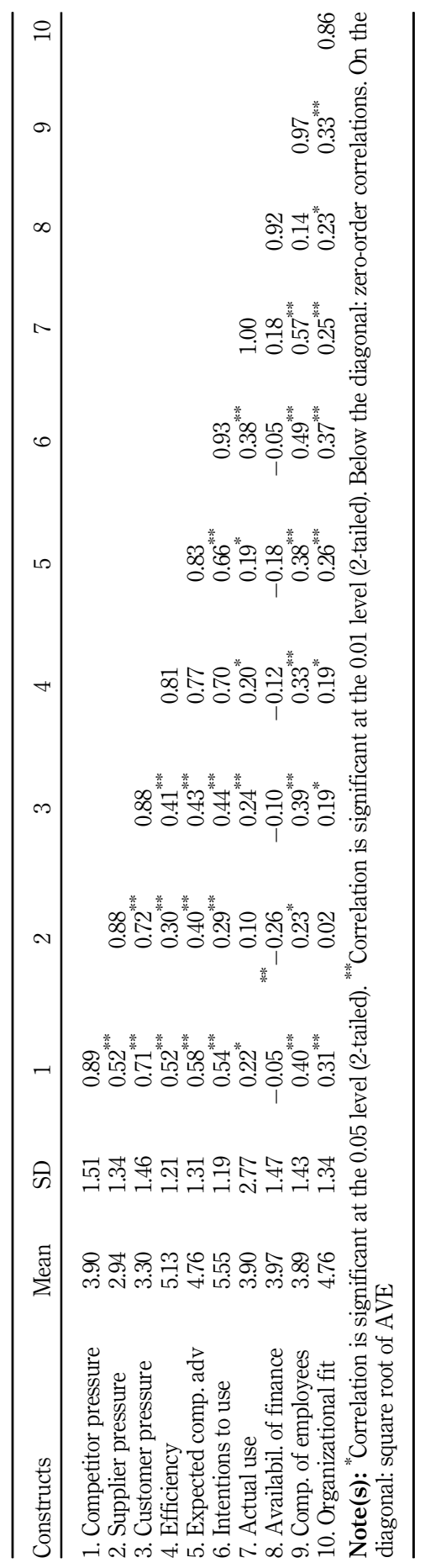

Industry 4.0 technologies usage

333

Table 3. Means, standard deviations (SD) and correlations 
JMTM 32,9

\section{4}

Table 4.

Results of testing the hypotheses for the structural model the construct ease of use (three items, Cronbach $\alpha=0.82$ ) as a marker variable that was theoretically unrelated to most of our substantive variables. After adjusting the zero-order correlations by partialing out this proxy, more than $90 \%$ of correlations remained significant as a result of this adjustment. Therefore, we can assume that the relationships in our model are unlikely to be inflated due to common method variance.

\subsection{Structural model}

The structural model has an acceptable fit $\chi^{2}=501.05$, $\mathrm{df}=214, p<0.001, \chi^{2} / \mathrm{df}=2.34$; RMSEA $=0.089,90 \% \mathrm{CI}$ is $0.079-0.099 ; \mathrm{SRMR}=0.078$; $\mathrm{CFI}=0.91 ; \mathrm{TLI}=0.90$ ). The results (Table 4) are in line with the proposed hypotheses for the relationships of efficiency motives with intentions to use I4 technologies (H4) and intentions to use with actual use (H6). For the other proactive motive (expected competitive advantage, $\mathrm{H} 5$ ), the relationships with intention to use are marginally significant and can be supported at $p^{<} 0.10$. Contrary to our propositions, none of the hypotheses for the effects of reactive motives on intention to use ( $\mathrm{H} 1, \mathrm{H} 2$, and $\mathrm{H} 3$ ) were supported. The control variable (company size) has a statistically significant effect on the intention to use, but not on actual use.

In addition, we tested the mediation effect of intention to use by conducting an analysis of bias-corrected bootstrap confidence intervals, as suggested by Preacher and Hayes (2008). Resampling 5,000 times and using a 95\% confidence interval (CI) for the parameter estimates, the results indicate an indirect effect of the efficiency motives through intention to use on actual use (indirect $\beta=0.359,95 \%$ bootstrapped $\mathrm{CI}=[0.064,0.819]$ ), while the indirect effects of other motives are not statistically significant. The mediation hypothesis (H7) is therefore supported only for efficiency motives.

\subsection{Analysis of moderation effects}

In the second step, we tested the moderation effects of the enablers (availability of finance, competency of employees and organizational fit) on the relationship between intention to use and actual use. We formulated a moderated mediation model (model 14) in PROCESS v3.0, where we used three main variables (efficiency as the independent variable, intention to use as the mediator and actual use as the dependent variable), moderators (each tested separately: availability of finance, competency of employees and organizational fit) and controls (all other motives, enablers and company size). The results (Table 5) indicate that the relationship between the intention to use and actual use is negatively moderated by the availability of finance (interaction effect is $-0.42, p=0.003$ ) and positively by the competency of employees (interaction effect is $0.31, p=0.067$ ), while organizational fit does not significantly moderate this relationship.

Probing reveals that for low levels of availability of finance ( -1 SD below the mean), the conditional effect size was $1.01(\phi=0.015 ; 95 \%$ CI [0.515, 2.100]). For medium levels of

\begin{tabular}{lccc}
\hline Hypotheses & $\begin{array}{c}\text { Proposed } \\
\text { direction }\end{array}$ & $\begin{array}{c}\text { Standardized path coefficient } \\
(t \text {-test })\end{array}$ & Hypothesis test \\
\hline H1: Competitor pressure $\rightarrow$ Intention to use & + & $0.08(0.73, p=0.466)$ & Not supported \\
H2: Supplier pressure $\rightarrow$ Intention to use & + & $-0.02(-0.12, p=0.897)$ & $\begin{array}{c}\text { Not supported } \\
\text { H3: Customer pressure } \rightarrow \text { Intention to use }\end{array}$ \\
H4: Efficiency $\rightarrow$ Intention to use & + & $0.02(0.14, p=0.868)$ & $\begin{array}{l}\text { Not supported } \\
\text { H5: Expected comp. adv. } \rightarrow \text { Intention to use }\end{array}$ \\
H6: Intention to use $\rightarrow$ Actual use & + & $0.40(3.13, p=0.002)$ & Supported \\
Control variables & + & $0.25(1.81, p=0.070)$ & Supported \\
Company size $\rightarrow$ Intention to use & / & $0.37(4.59, p=0.000)$ & Supported \\
Company size $\rightarrow$ Actual use & $/$ & $0.19(2.63, p=0.009)$ & $/$ \\
& & $0.12(1.41, p=0.157)$ & $/$
\end{tabular}




\begin{tabular}{|c|c|c|c|}
\hline Variables & $\begin{array}{l}\text { Actual use (moderator: } \\
\text { availability of finance) }\end{array}$ & $\begin{array}{l}\text { Actual use (moderator: } \\
\text { competency of employees) }\end{array}$ & $\begin{array}{l}\text { Actual use (moderator: } \\
\text { organizational fit) }\end{array}$ \\
\hline Constant & $0.81(t=1.78, p=0.46)$ & $5.08(t=2.54, p=0.10)$ & $0.98(t=0.54, p=0.59)$ \\
\hline Efficiency (IV) & $0.07(t=0.21 ; p=0.84)$ & $-0.13(t=-0.40 ; p=0.69)$ & $-0.09(t=-0.27 ; p=0.78)$ \\
\hline Intention to use (M) & $0.72(t=2.36 ; p=0.02)$ & $0.73(t=2.22 ; p=0.03)$ & $0.52(t=1.72 ; p=0.09)$ \\
\hline \multicolumn{4}{|c|}{ Moderators (tested separately) } \\
\hline $\begin{array}{l}\text { Availability of finance } \\
\text { (W1) }\end{array}$ & $0.19(t=1.17, p=0.27)$ & $0.06(t=0.33, p=0.74)$ & $0.23(t=1.29, p=0.20)$ \\
\hline $\begin{array}{l}\text { Competency of employees } \\
\text { (W2) }\end{array}$ & $0.89(t=4.70, p<0.01)$ & $0.78(t=4.04, p<0.01)$ & $0.87(t=4.44, p<0.01)$ \\
\hline Organizational fit (W3) & $0.05(t=0.28, p=0.78)$ & $-0.03(t=-0.14, p=0.88)$ & $0.01(t=0.03, p=0.98)$ \\
\hline Interaction effect & $-0.42(t=-3.01, p=0.003)$ & $0.31(t=1.86, p=0.067)$ & $-0.25(t=1.66, p=0.100)$ \\
\hline \multicolumn{4}{|l|}{ Control variables } \\
\hline Competitor pressure & $-0.23(t=-1.02, p=0.31)$ & $-0.22(t=-0.92, p=0.36)$ & $-0.18(t=-0.76, p=0.45)$ \\
\hline Supplier pressure & $0.05(t=0.20, p=0.85)$ & $0.11(t=0.43, p=0.67)$ & $0.07(t=0.29, p=0.78)$ \\
\hline Customer pressure & $0.23(t=0.86, p=0.39)$ & $0.17(t=0.62, p=0.54)$ & $0.12(t=0.43, p=0.67)$ \\
\hline Expected comp. adv & $-0.22(t=-0.77, p=0.44)$ & $-0.20(t=-0.69, p=0.49)$ & $-0.15(t=-0.52, p=0.61)$ \\
\hline Company size & $0.56(t=1.16, p=0.25)$ & $0.72(t=1.45, p=0.15)$ & $0.57(t=1.14, p=0.26)$ \\
\hline$R^{2}$ & 0.39 & 0.36 & 0.35 \\
\hline$F$ & 5.55 & 4.78 & 4.69 \\
\hline Conditional indirect & 0.33 & 0.34 & 0.24 \\
\hline
\end{tabular}
diated) effect $95 \%$ BC CI

(LLCI 0.051, ULCI 0.728)

(LLCI 0.049, ULCI 0.753)

(LLCI -0.047, ULCI 0.597)

Note(s): IV = independent variable. $\mathrm{M}=$ mediator. $\mathrm{W}=$ moderator. Unstandardized coefficients are reported. LLCI = lower-level confidence interval. ULCI = upper-level confidence interval
Industry 4.0 technologies usage

335

Table 5.

Results of the moderated-mediation analyses with the PROCESS macro (Model 14)

availability of finance, the conditional effect size was 0.72 ( $\phi=0.020 ; 95 \%$ CI $[0.114,1.317]$ ). For high levels of availability of finance ( $+1 \mathrm{SD}$ above the mean), the conditional effect size was $0.12(p=0.70 ; 95 \%$ CI $[-0.510,0.757])$. For low and medium availability of finance, there is a positive relationship between the intention to use and actual use, while with a high availability of finance there is no relationship between the intention to use and actual use. These results identify the availability of finance as a negative moderator of the relationship between the intention to use and actual use (Figure 2). Moderation exists, but is not in line with the direction proposed in $\mathrm{H} 8$.

Further, probing reveals that for low levels of competency of employees $(-1$ SD below the mean), the conditional effect size was 0.29 ( $p=0.378$; 95\% CI [ $-0.355,0.927])$. For medium

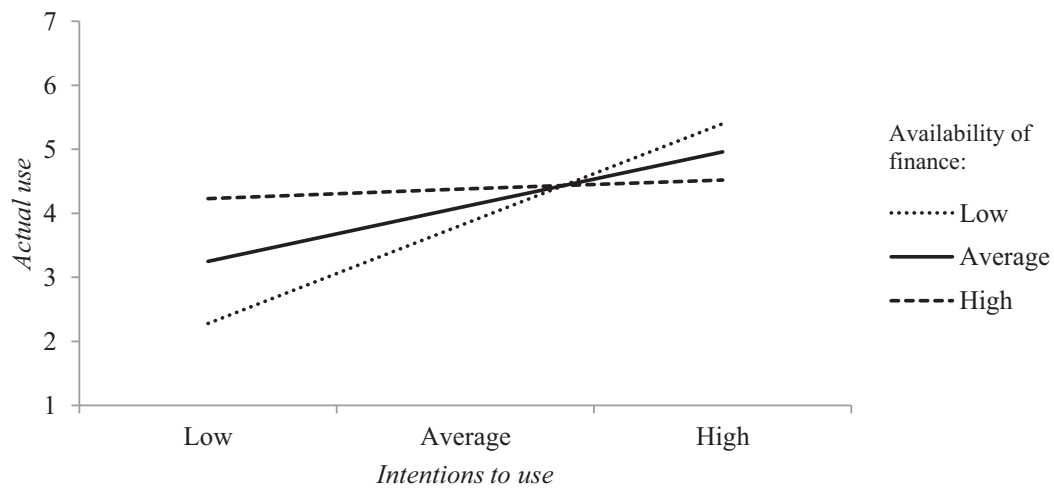

Figure 2.

The moderating role of availability of finance in the relationship between intentions to use and actual use 
JMTM 32,9

336

levels of competency of employees, the conditional effect size was $0.73(p=0.029 ; 95 \%$ CI $[0.077,1.373]$ ). For high levels of competency of employees ( +1 SD above the mean), the conditional effect size was $1.16(p=0.015 ; 95 \%$ CI [0.231, 2.097]). For low values of competency of employees, there is no relationship between the intention to use and actual use, while for medium and high levels of competency of employees there is a positive relationship between the intention to use and actual use. These results identify the competency of employees as a positive moderator in the relationship between intention to use and actual use (Figure 3). H9 is therefore supported.

The final model, which shows all the statistically significant links among the constructs, is presented in Figure 4.

\section{Discussion}

\subsection{Theoretical implications}

The discussion of theoretical implications and contributions that follows is organized in three parts to ensure greater clarity: (1) contributions on motives, (2) contributions on enablers and (3) a combination of the two (the overarching theoretical framework).

Figure 3.

The moderating role of employees' competencies in the relationship between intentions to use and actual use
Figure 4.

The final model with results
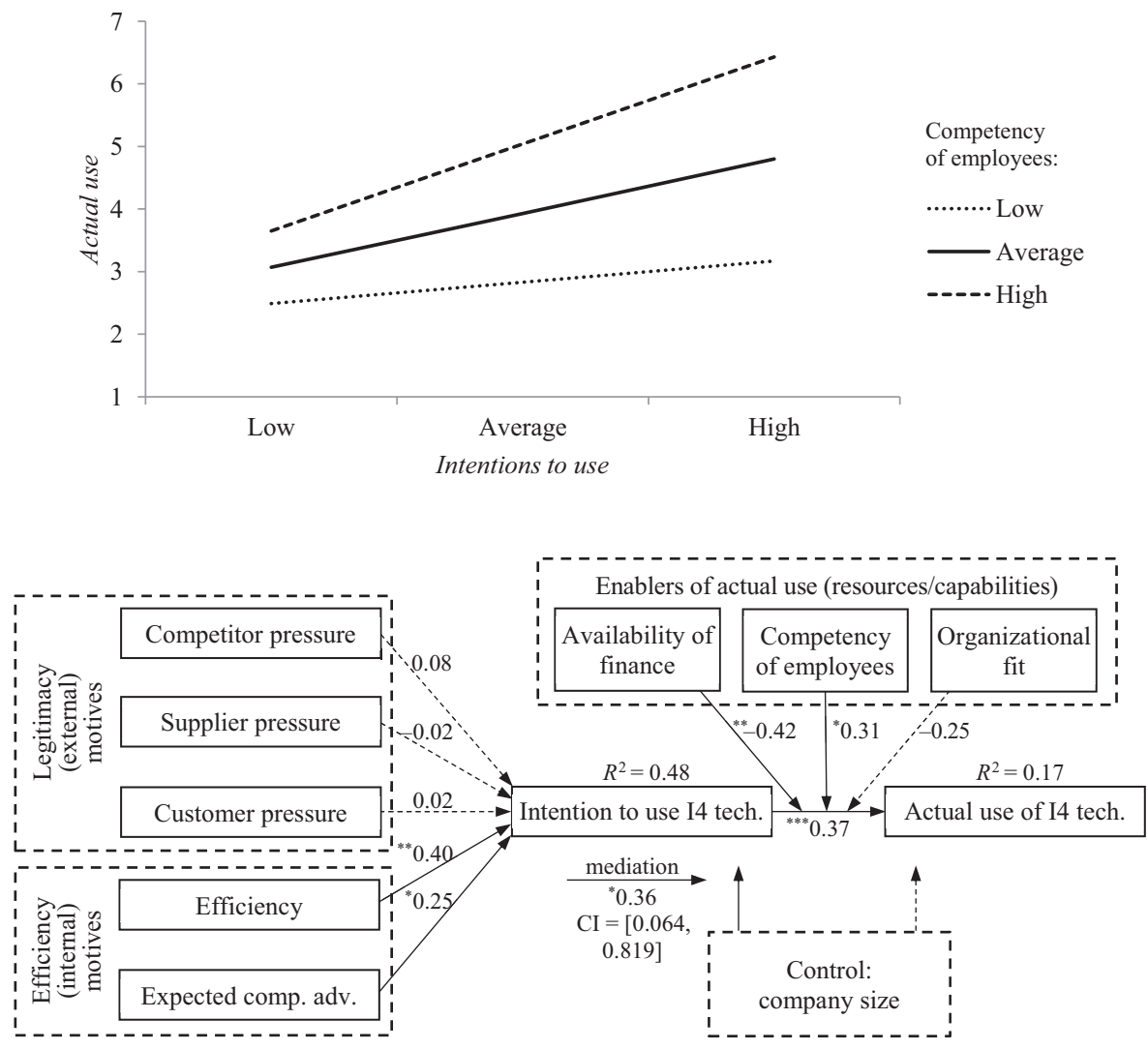

Note(s): Solid arrows $=$ supported hypotheses. Dashed arrows $=$ unsupported hypotheses.

$* p<0.1{ }^{* *} p<0.01 .{ }^{* * *} p<0.001$ 


\section{(1) Implications/contribution related to motives}

Regarding motives (the antecedents in our model), we find that companies' intentions to use I4 technologies are significantly influenced by the expected increase in efficiency and competitive advantage and not by external normative pressures from suppliers or customers or even by mimetic pressures from competitors. This means that legitimacy (external) motives do not play a significant role in developing the intention to use I4 technologies, which runs counter to the propositions and findings of certain previous studies (Chwelos et al., 2001; Son and Benbasat, 2007; Ghobakhloo and Ching, 2019). Instead, the motivation to consider adopting I4 technologies seems to be driven by efficiency (internal) motives, as also indicated in several earlier studies (Grewal et al., 2001; Tsai et al., 2005; Son and Benbasat, 2007; Kim et al., 2008, 2009; Obal, 2017). We believe two main reasons explain these results. The first may be that companies with efficiency-driven motives better understand new technology and therefore have more realistic expectations about its benefits (Rask and Kragh, 2004), which may increase their intention to use. The second reason may be that customers and suppliers of many of the surveyed companies were still not using I4 technologies, which means the surveyed companies had felt no pressure from external parties to start using I4 technologies.

In any case, the greater importance of the efficiency over the legitimacy factors leads us to conclude that companies are approaching I4 proactively instead of reactively. This means they are trying to introduce initiatives ahead of their competitors, seize market opportunities, take the lead in the market and build competitive advantages, instead of focusing on adapting to the stakeholders' requests/needs, reacting to the changing environment or responding to competitors' challenges (Chen et al., 2012). The above results are in line with the technology adoption life cycle framework (Moore, 2006), where the first three groups (technology enthusiasts, visionaries and pragmatists) represent proactive technology adopters, while the latter groups on the adoption curve (conservatives and skeptics) are reactive adopters. Visionaries seek out technologies that offer the biggest scope for benefitting the business (competitive advantage), while pragmatists look for proven products and care for effectiveness and efficiency. Given that in the examined market firms are still in the relatively early stages of adoption, our findings are consistent with Moore's (2006) framework.

Our results related to the motives are important because they help us understand in a more structured way why companies consider introducing I4 technologies. Although the UTAUT (Venkatesh et al., 2003) model already includes motives for technology acceptance in the discussion, this inclusion has been on the individual level, whereas our research discusses motives on the organizational level (i.e. instead of individual-level performance expectancy and social influence in the UTAUT, we are focused on firm-level efficiency and legitimacy motives). By linking the motivation perspective based on the transaction cost and institutional theories (Roberts and Greenwood, 1997; Grewal et al., 2001; Son and Benbasat, 2007) with the political-economic framework (Stern and Reve, 1980) and stakeholder theory (Freeman, 1984), our theoretical contribution is therefore linked to more systematic inclusion of external/reactive vs internal/proactive organizational-level motives in the technology acceptance literature.

(2) Implications/contribution related to enablers

As for the link between intended and actual use and the enablers that moderate it, our study finds that intentions to use are significantly related to actual use. This is no surprise and consistent with several previous studies (Davis et al., 1989; Taylor and Todd, 1995; Venkatesh and Davis, 2000; Venkatesh et al., 2000, 2003, 2012; Yi and Hwang, 2003). However, the way our study contributes is by adding enablers that moderate (thus answering Palmatier's (2016) call to include moderators) the link between intended and actual use. Although the literature
Industry 4.0 technologies usage 
JMTM 32,9

338 (e.g. Neto et al., 2017) has already discussed the lack of enablers, such as competent employees, sufficient finance and organizational fit, these enablers have not yet been conceptualized as moderators in a structural model.

This study confirms competency of employees to be an important enabler of actual use, which is in line with several previous studies that show employees play a decisive role in new technology implementation (Stanton Chase, 2017; Müller et al., 2018b; Ghobakhloo and Ching, 2019). Not only does the competency of employees have a direct positive effect on the actual use of I4, they also function as an enabler of implementation, meaning that the more competent the employees are, the stronger the effect of the intention to use on actual use is. On the other hand, availability of finance impacts this relationship in an opposite manner. In conditions with lower and medium finance availability, the relationship between intentions to use and actual use is strengthened; however, after a certain point (high availability of finance), this relationship is not significant. This could mean that companies which have enough financial resources do not see finance as a critical enabler of their actual use of I4 technologies. The direct effect of this enabler on actual use is also not statistically significant. This is in contrast to findings of some previous studies (Davila et al., 2003; Silvestre and Silva Neto, 2014) and could be context-specific. Organizational fit does not act as an enabler or barrier to actual use of I4 (which is in contrast with Ghobakhloo and Ching (2019) who found it to be an important factor of I4 adoption), meaning that companies do not perceive difficulties in integrating I4's novel manufacturing paradigm into existing organizational and production systems.

Our results related to enablers confirm that the intended-actual use relationship may be more complex, i.e. it may include boundary conditions (moderators) for transforming intentions into actual use. By confirming resources/capabilities as firm-level boundary conditions in our model, our study integrates the RCBV framework (Barney, 1991; Winter, 2003) with the TAM (Davis, 1986; Davis et al., 1989) and UTAUT (Venkatesh et al., 2003) models, therefore providing a theoretical contribution to the technology acceptance literature. The RCBV adds an important perspective to the fact that motives leading to intentions are only a necessary (but not a sufficient) factor in achieving actual use and that transforming intentions into implementation first requires adequate resources/capabilities. This perspective is in line with the UTAUT (which also assumes that actual use is influenced by behavioral intention and facilitating conditions (Escobar-Rodríguez and Carvajal-Trujillo, 2014)), but still different by conceptualizing the facilitating conditions as moderators.

\section{(3) Overarching theoretical framework}

As discussed, our study combines several theoretical approaches with the aim to develop a more comprehensive framework of the complex interactions between relevant variables that lead to the actual use of I4 technologies. First, a combination of the transaction cost and institutional theories (Roberts and Greenwood, 1997; Grewal et al., 2001; Son and Benbasat, 2007) is used to contribute to the UTAUT (Venkatesh et al., 2003) literature by more systematically analyzing the motives for technology usage. Then, the RCBV (Barney, 1991; Winter, 2003) is applied to add to the TAM (Davis, 1986; Davis et al., 1989) and UTAUT models by offering sound argumentation of enablers that moderate the link between intended and actual use. By combining these theoretical approaches, we develop an overarching theoretical framework in the field of I4 technology usage (a kind of extension of the UTAUT model) and, hopefully, contribute to the construction of a more cohesive and consistent theory on technology acceptance.

\subsection{Practical implications}

Our empirical findings hold several practical implications. While some are general (i.e. not context-specific), some should be interpreted with respect to the specific geographical and 
contextual setting of the study (i.e. a small open Central and Eastern European (CEE) economy in which companies are strongly embedded in the global value chains of large international players).

From the managerial perspective, I4 technologies' providers and partners along the global value chains should first keep in mind that (contrary to our expectations) value chain pressure is not an important motive for using I4 technologies. Instead, potential technology users seem motivated by internal rational factors and initially wish to understand measurable gains before they develop an intention to use the technology. Consequently, even if the use of I4 technologies is expected by the main global value chain players, they should still primarily point out the measurable efficiency and competitive gains for other value chain participants instead of just applying normative pressure to them. Second, potential I4 technology users should strengthen their search efforts and concentrate on finding technologies that can help them improve their competitive position and avoid lagging as a result of a geographically specific "doing business as usual" approach. Third, understanding how the motivation for technology adoption works promotes cooperative approaches to building mutually beneficial and experience-sharing-based long-term relationships between the main global players and their (CEE-based) value chain partners. Fourth, the results reveal the importance of employees' competencies as an enabler of I4 technology usage, which implies that a complementary investment in training is needed to enable employees to work with new technologies and fully utilize their potential.

In addition, our study has important policy implications. First, policymakers not only have a pivotal role to play in promoting awareness about the need for digitalization but also hold the power to tailor financially supported national development programs that support technology modernization. Second, policymakers should rethink human capital development on the national level and focus on the identified need for complementarity between investment in technology and human competencies. Third, education and training with future knowledge and skills needs in mind is also important in view of broader labor market challenges, including an ageing population, and should adopt a comprehensive approach to skills matching and skills shortages through formal education, life-long learning and on-thejob training.

As this is the first such systematic study on drivers of I4 technology usage in this geographical/contextual setting, managers and policymakers can learn from our conclusions to improve the use of I4 technology on both organizational and economy levels. This is especially critical in small emerging economies were being part of international value chains is not only important for internationally oriented companies but also for the survival of domestic supply chains along with whole clusters of small local companies.

\section{Conclusion}

Our paper adds to the body of knowledge on I4 technologies by clearly distinguishing between the motives and enablers of I4 technology usage. While the motives play the role of antecedents of the intention to use I4 technologies, the enablers moderate the link between the intended and actual use of these technologies. Motives therefore only provide a necessary (but not a sufficient) factor of actual use, whereas enablers (resources/capabilities) are needed to leverage intentions into actual use. The results show that only efficiency motives have a positive effect on the intention to use I4 technologies (which in turn positively influences their actual use) and that employee competencies act as a key enabler that positively enhances the relationship between the intended and actual use of I4 technologies.

The main limitation of our study is connected to the relatively small population that is dependent on the size of the economy. Due to the survey being lengthy, the number of companies that finished it was relatively low. With a larger sample size, the results would be
Industry 4.0 technologies

usage

339 
JMTM 32,9

\section{0}

more stable and possibly more effects would be statistically significant. Therefore, future studies should test our model by using a focused survey questionnaire in other contexts/ economies which would enable us to provide more conclusive evidence on how and why I4 technology is adopted (in general and in countries that are followers of the global development). If the sample was larger, we could also analyze subsamples and create some sort of typology for industries. Given the differences between manufacturing industries, it would be beneficial to conduct industry-specific studies, which would then allow us to examine both the depth and breadth of I4 technologies usage as outcome variables. Future research is therefore welcome to continue advancing our understanding of motives and enablers for I4 technology adoption in specific industries and different contexts.

\section{References}

Anderson, J.C. and Gerbing, D.W. (1988), "Structural equation modeling in practice: a review and recommended two-step approach”, Psychological Bulletin, Vol. 103 No. 3, pp. 411-423.

Banerjee, S.B., Iyer, E.S. and Kashyap, R.K. (2003), "Corporate environmentalism: antecedents and influence of industry type", Journal of Marketing, Vol. 67 No. 2, pp. 106-122.

Barney, J. (1991), "Firm resources and sustained competitive advantage", Journal of Management, Vol. 17 No. 1, pp. 99-120.

Bauer, W., Hämmerle, M., Schlund, S. and Vocke, C. (2015), "Transforming to a hyper-connected society and economy - towards an 'Industry 4.0”, Procedia Manufacturing, Vol. 3, pp. 417-424.

Benders, J., Batenburg, R. and van der Blonk, H. (2006), "Sticking to standards: technical and other isomorphic pressures in deploying ERP-systems", Information and Management, Vol. 43, pp. 194-203.

Bharati, P. and Chaudhury, A. (2004), "An empirical investigation of decision-making satisfaction in web-based decision support systems”, Decision Support Systems, Vol. 37, pp. 187-197.

Bhattacherjee, A. and Premkumar, G. (2004), "Understanding changes in belief and attitude toward information technology usage: a theoretical model and longitudinal test”, MIS Quarterly, Vol. 28 No. 2, pp. 229-254.

Bieńkowska, A. and Tworek, K. (2021), "The moderating role of IT in process of shaping organizational performance by dynamic capabilities of controlling”, Applied Sciences, Vol. 11 No. 2, p. 889.

Bosman, L., Hartman, N. and Sutherland, J. (2020), "How manufacturing firm characteristics can influence decision making for investing in Industry 4.0 technologies", Journal of Manufacturing Technology Management, Vol. 31 No. 5, pp. 1117-1141.

Brettel, M., Friederichsen, N., Keller, M. and Rosenberg, M. (2014), "How virtualization, decentralization and network building change the manufacturing landscape: an Industry 4.0 Perspective", International Journal of Mechanical, Industrial Science and Engineering, Vol. 8 No. 1, pp. 37-44.

Büchi, G., Cugno, M. and Castagnoli, R. (2020), "Smart factory performance and Industry 4.0", Technological Forecasting and Social Change, Vol. 150, 119790.

Čater, B., Čater, T., Černe, M., Koman, M. and Redek, T. (2019), "New Industry 4.0 technologies in small and medium-sized firms in Slovenia”, Economic and Business Review, Vol. 21, Special issue, pp. 175-184.

Chau, P.K.W. and Tam, K.Y. (1997), "Factors affecting the adoption of open systems: an exploratory study", MIS Quarterly, Vol. 21 No. 1, pp. 1-24.

Chen, Y.S., Chang, C.H. and Wu, F.S. (2012), "Origins of green innovations: the differences between proactive and reactive green innovations", Management Decision, Vol. 50 No. 3, pp. 368-398.

Chwelos, P., Benbasat, I. and Dexter, A.S. (2001), "Research report: empirical test of an EDI adoption model”, Information Systems Research, Vol. 12 No. 3, pp. 304-321. 
Cimini, C., Boffelli, A., Lagorio, A., Kalchschmidt, M. and Pinto, R. (2021), "How do Industry 4.0 technologies influence organisational change? An empirical analysis of Italian SMEs", Journal of Manufacturing Technology Management, Vol. 32 No. 3, pp. 695-721.

Cumming, G.S. (2014), "Theoretical frameworks for the analysis of social-ecological systems", in Shoko, S. and Umetsu, C. (Eds), Social-ecological Systems in Transition, Springer, Berlin, pp. 3-24.

Davila, A., Gupta, M. and Palmer, R. (2003), "Moving procurement systems to the internet: the adoption and use of e-procurement technology models", European Management Journal, Vol. 21 No. 1, pp. 11-23.

Davis, F.D. (1986), A Technology Acceptance Model for Empirical Testing New End-User Information System: Theory and Results, Massachusetts Institute of Technology, Cambridge.

Davis, F.D., Bagozzi, R.P. and Warshaw, P.R. (1989), "User acceptance of computer technology: a comparison of two theoretical models", Management Science, Vol. 35 No. 8, pp. 982-1003.

Dos Santos, L.M.A.L., Da Costa, M.B., Kothe, J.V., Benitez, G.B., Schaefer, J.L., Baierle, I.C. and Benitez Nara, E.O. (2021), "Industry 4.0 collaborative networks for industrial performance", Journal of Manufacturing Technology Management, Vol. 32 No. 2, pp. 245-265.

Erol, S., Jäger, A., Hold, P., Ott, K. and Sihn, W. (2016), “Tangible Industry 4.0: a scenario-based approach to learning for the future of production”, Procedia CIRP, Vol. 54, pp. 13-18.

Escobar-Rodríguez, T. and Carvajal-Trujillo, E. (2014), "Online purchasing tickets for low cost carriers: an application of the unified theory of acceptance and use of technology (UTAUT) model", Tourism Management, Vol. 43, pp. 70-88.

Fornell, C. and Larcker, D.F. (1981), "Evaluating structural equation models with unobservable variables and measurement error", Journal of Marketing Research, Vol. 18 No. 1, pp. 39-50.

Frank, A.G., Dalenogare, L.S. and Ayala, N.F. (2019), "Industry 4.0 technologies: Implementation patterns in manufacturing companies", International Journal of Production Economics, Vol. 210, pp. 15-26.

Freeman, R.E. (1984), Strategic Management: A Stakeholder Approach, Pitman, Boston.

Gao, T., Leichter, G. and Wei, Y. (2012), "Countervailing effects of value and risk perceptions in manufacturers' adoption of expensive, discontinuous innovations", Industrial Marketing Management, Vol. 41 No. 4, pp. 659-668.

Gatignon, H. and Robertson, T.S. (1989), "Technology diffusion: an empirical test of competitive effects", Journal of Marketing, Vol. 53 No. 1, pp. 35-49.

Ghobakhloo, M. (2018), "The future of manufacturing industry: a strategic roadmap toward Industry 4.0", Journal of Manufacturing Technology Management, Vol. 29 No. 6, pp. 910-936.

Ghobakhloo, M. (2020), "Industry 4.0, digitization, and opportunities for sustainability", Journal of Cleaner Production, Vol. 252, 119869.

Ghobakhloo, M. and Ching, N.T. (2019), "Adoption of digital technologies of smart manufacturing in SMEs", Journal of Industrial Information Integration, Vol. 16, 100107.

Gombault, M. and Versteege, S. (1999), "Cleaner production in SMEs through a partnership with (local) authorities: successes from The Netherlands", Journal of Cleaner Production, Vol.7 No. 4, pp. 249-261.

Grewal, R., Comer, J.M. and Mehta, R. (2001), "An investigation into the antecedents of organizational participation in business-to-business electronic markets", Journal of Marketing, Vol. 65 No. 3, pp. 17-33.

Hermann, M., Bücker, I. and Otto, B. (2019), “Industrie 4.0 process transformation: findings from a case study in automotive logistics", Journal of Manufacturing Technology Management, Vol. 31 No. 5, pp. 935-953.

Johansson, P.E.C., Malmsköld, L., Fast-Berglund, Å. and Moestam, L. (2019), “Challenges of handling assembly information in global manufacturing companies", Journal of Manufacturing Technology Management, Vol. 31 No. 5, pp. 955-976. 
JMTM 32,9

342

Kamble, S.S., Gunasekaran, A. and Sharma, R. (2018), "Analysis of the driving and dependence power of barriers to adopt Industry 4.0 in Indian manufacturing industry", Computers in Industry, Vol. 101 No. 1, pp. 107-119.

Karahanna, E., Straub, D.W. and Chervany, N.L. (1999), "Information technology adoption across time: a cross-sectional comparison of pre-adoption and post-adoption beliefs", Mis Quarterly, Vol. 23 No. 2, pp. 183-213.

Kim, T.T., Lee, J. and Law, R. (2008), “An empirical examination of the acceptance behaviour of hotel front office systems: an extended technology acceptance model”, Tourism Management, Vol. 29, pp. 500-513.

Kim, H., Kim, T.T. and Shin, S. (2009), "Modeling roles of subjective norms and eTrust in customers' acceptance of airline B2C eCommerce websites", Tourism Management, Vol. 30, pp. 266-277.

Lacka, E. and Chong, A. (2016), "Usability perspective on social media sites' adoption in the B2B context", Industrial Marketing Management, Vol. 54, pp. 80-91.

Lee, B.W. and Green, K. (1994), "Towards commercial and environmental excellence: a green portfolio matrix", Business Strategy and the Environment, Vol. 3 No. 3, pp. 1-9.

Liao, Y., Deschamps, F., Loures, E.D.F.R. and Ramos, L.F.P. (2017), "Past, present and future of Industry 4.0: a systematic literature review and research agenda proposal", International Journal of Production Research, Vol. 55 No. 12, pp. 3609-3629.

Lindell, M. and Whitney, D. (2001), "Accounting for common method variance in cross-sectional research design", The Journal of Applied Psychology, Vol. 86 No. 1, pp. 114-121.

Linz, C., Müller-Stewens, G. and Zimmermann, A. (2017), Radical Business Model Transformation: Gaining the Competitive Edge in a Disruptive World, Kogan Page, London.

Liu, J., Baskaran, A. and Li, S. (2009), "Building technological-innovation-based strategic capabilities at firm level in China: a dynamic resource-based-view case study", Industry and Innovation, Vol. 16 Nos 4-5, pp. 411-434.

Mariani, M. and Borghi, M. (2019), "Industry 4.0: a bibliometric review of its managerial intellectual structure and potential evolution in the service industries", Technological Forecasting and Social Change, Vol. 149, 119752.

Momani, A.M. and Jamous, M. (2017), "The evolution of technology acceptance theories", International Journal of Contemporary Computer Research, Vol. 1, pp. 50-58.

Moore, G.A. (2006), Crossing the Chasm: Marketing and Selling Disruptive Products to Mainstream Customers, Harper Business Essentials, New York.

Müller, J., Buliga, O. and Voigt, K.-I. (2018a), "Fortune favors the prepared: how SMEs approach business model innovations in Industry 4.0", Technological Forecasting and Social Change, Vol. 132, July, pp. 2-17.

Müller, J.M., Kiel, D. and Voigt, K.-I. (2018b), "What drives the implementation of Industry 4.0? The role of opportunities and challenges in the context of sustainability", Sustainability, Vol. 10 No. 1, p. 247.

Neto, G.C.O., Leite, R.R., Shibao, F.Y. and Lucato, W.C. (2017), "Framework to overcome barriers in the implementation of cleaner production in small and medium-sized enterprises: multiple case studies in Brazil", Journal of Cleaner Production, Vol. 142, pp. 50-62.

Nosalska, K., Piạtek Zbigniew, M., Mazurek, G. and Rządca, R. (2019), "Industry 4.0: coherent definition framework with technological and organizational interdependencies", Journal of Manufacturing Technology Management, Vol. 31 No. 5, pp. 837-862.

Obal, M. (2017), "What drives post-adoption usage? Investigating the negative and positive antecedents of disruptive technology continuous adoption intentions", Industrial Marketing Management, Vol. 63, pp. 42-52. 
Oesterreich, T.D. and Teuteberg, F. (2016), "Understanding the implications of digitisation and automation in the context of Industry 4.0: a triangulation approach and elements of a research agenda for the construction industry", Computers in Industry, Vol. 83, pp. 121-139.

Palmatier, R.W. (2016), "Improving publishing success at JAMS: contribution and positioning", Journal of the Academy of Marketing Science, Vol. 44, pp. 655-659.

Park, S.H. and Lee, Y.G. (2011), "Perspectives on technology transfer strategies of Korean companies in point of resource and capability based view", Journal of Technology Management and Innovation, Vol. 6 No. 1, pp. 161-184.

Piccarozzi, M., Aquilani, B. and Gatti, C. (2018), "Industry 4.0 in management studies: a systematic literature review", Sustainability, Vol. 10, p. 3821.

Pirola, F., Cimini, C. and Pinto, R. (2019), "Digital readiness assessment of Italian SMEs: a case-study research", Journal of Manufacturing Technology Management, Vol. 31 No. 5, pp. 1045-1083.

Podsakoff, P.M., MacKenzie, S.B. and Podsakoff, N.P. (2012), "Sources of method bias in social science research and recommendations on how to control it", Annual Review of Psychology, Vol. 63 No. 1, pp. 539-569.

Posada, J., Toro, C., Barandiaran, I., Oyarzun, D., Stricker, D., De Amicis, R., Pinto, E.B., Eisert, P., Döllner, J. and Vallarino, I. (2015), "Visual computing as a key enabling technology for Industry 4.0 and industrial internet", IEEE Computer Graphics and Applications, Vol. 35, pp. $26-40$.

Preacher, K.J. and Hayes, A.F. (2008), "Asymptotic and resampling strategies for assessing and comparing indirect effects in multiple mediator models", Behavior Research Methods, Vol. 40 No. 3, pp. 879-891.

Rachinger, M., Rauter, R., Müller, C., Vorraber, W. and Schirgi, E. (2019), "Digitalization and its influence on business model innovation”, Journal of Manufacturing Technology Management, Vol. 30 No. 8, pp. 1143-1160.

Ramdani, B., Kawalek, P. and Lorenzo, O. (2009), "Predicting SMEs' adoption of enterprise systems", Journal of Enterprise Information Management, Vol. 22 Nos 1/2, pp. 10-24.

Rask, M. and Kragh, H. (2004), "Motives for e-marketplace participation: differences and similarities between buyers and suppliers", Electronic Markets, Vol. 14, pp. 270-283.

Roberts, P.W. and Greenwood, R. (1997), "Integrating transaction cost and institutional theories: toward a constrained-efficiency framework for understanding organizational design adoption", Academy of Management Review, Vol. 22 No. 2, pp. 346-373.

Sanders, A., Elangeswaran, C. and Wulfsberg, J.P. (2016), "Industry 4.0 implies lean manufacturing: research activities in Industry 4.0 function as enablers for lean manufacturing", Journal of Industrial Engineering and Management, Vol. 9 No. 3, pp. 811-833.

Schermelleh-Engel, K., Moosbrugger, H. and Müller, H. (2003), "Evaluating the fit of structural equation models: tests of significance and descriptive goodness-of-fit measures", Methods of Psychological Research Online, Vol. 8 No. 2, pp. 23-74.

Scott, W.R. (1987), “The adolescence of institutional theory”, Administrative Science Quarterly, Vol. 32 No. 4, pp. 493-511.

Silvestre, B.S. and Silva Neto, R.E. (2014), "Are cleaner production innovations the solution for small mining operations in poor regions? The case of Padua in Brazil", Journal of Cleaner Production, Vol. 84, pp. 809-817.

Son, J.Y. and Benbasat, I. (2007), "Organizational buyers' adoption and use of B2B electronic marketplaces: efficiency- and legitimacy-oriented perspectives", Journal of Management Information Systems, Vol. 24 No. 1, pp. 55-99.

Stanton Chase (2017), "2017 global industrial survey: leadership in the industrial landscape”, available at: https://www.stantonchase.com/wp-content/uploads/2017/04/2017-Global-Industrial-Survey. pdf (accessed 20 September 2018). 
JMTM 32,9

\section{4}

Staufen (2018), “German Industry 4.0 index 2018”, available at: https:/www.staufen.ag/fileadmin/HQ/ 02-Company/05-Media/2-Studies/STAUFEN.-Study-Industry-4.0-Index-2018-Web-DE-en.pdf (accessed 20 September 2018).

Stern, L.W. and Reve, T. (1980), "Distribution channels as political economies: a framework for comparative analysis", Journal of Marketing, Vol. 44 No. 3, pp. 52-64.

Szalavetz, A. (2019), "Industry 4.0 and capability development in manufacturing subsidiaries", Technological Forecasting and Social Change, Vol. 145, pp. 384-395.

Taylor, S. and Todd, P.A. (1995), "Understanding information technology usage: a test of competing models", Information Systems Research, Vol. 6 No. 2, pp. 144-176.

Tellis, G.J. (2006), "Disruptive technology or visionary leadership?", The Journal of Product Innovation Management, Vol. 23 No. 1, pp. 34-38.

Tsai, H.-T., Huang, L. and Lin, C.-G. (2005), "Emerging e-commerce development model for Taiwanese travel agencies", Tourism Management, Vol. 26, pp. 787-796.

Veile, J.W., Kiel, D., Müller, J.M. and Voigt, K.-I. (2019), "Lessons learned from Industry 4.0 implementation in the German manufacturing industry", Journal of Manufacturing Technology Management, Vol. 31 No. 5, pp. 977-997.

Veile, J.W., Schmidt, M.-C., Müller, J.M. and Voigt, K.-I. (2020), "Relationship follows technology! How Industry 4.0 reshapes future buyer-supplier relationships", Journal of Manufacturing Technology Management, Vol. ahead-of-print No. ahead-of-print, doi: 10.1108/JMTM-092019-0318.

Venkatesh, V. and Davis, F. (2000), “A theoretical extension of the technology acceptance model: four longitudinal field studies", Management Science, Vol. 46, pp. 186-204.

Venkatesh, V., Morris, M.G. and Ackerman, P.L. (2000), "A longitudinal field investigation of gender differences in individual technology adoption decision-making processes", Organizational Behavior and Human Decision Processes, Vol. 83 No. 1, pp. 33-60.

Venkatesh, V., Morris, M.G., Davis, G.B. and Davis, F.D. (2003), "User acceptance of information technology: toward a unified view", MIS Quarterly, Vol. 27 No. 3, pp. 425-478.

Venkatesh, V., Thong, J.Y.L. and Xu, X. (2012), "Consumer acceptance and use of information technology: extending the unified theory of acceptance and use of technology", MIS Quarterly, Vol. 36 No. 1, pp. 157-178.

Winter, S.G. (2003), "Understanding dynamic capabilities", Strategic Management Journal, Vol. 24 No. 10, pp. 991-995.

Yi, M. and Hwang, Y. (2003), "Predicting the use of web-based information systems: self-efficacy, enjoyment, learning goal orientation, and the technology acceptance model", International Journal of Human-Computer Studies, Vol. 59, pp. 431-449.

Zheng, T., Ardolino, M., Bacchetti, A., Perona, M. and Zanardini, M. (2019), "The impacts of Industry 4.0: a descriptive survey in the Italian manufacturing sector", Journal of Manufacturing Technology Management, Vol. 31 No. 5, pp. 1085-1115.

\section{About the authors}

Tomaž Cater, Ph.D., is a Full Professor of Management at the School of Economics and Business, University of Ljubljana, Slovenia. External to the faculty he was a member of the management board of the European Academy of Management (EURAM) and the president of the Slovenian Academy of Management (SAM). His main fields of research are competitive advantages of firms and corporate social and environmental responsibility. He has also worked as a visiting professor at universities in Indiana (USA), Chemnitz and Regensburg (Germany), and Dubai (UAE), among others. He is the author or co-author of 60 scientific articles in journals, including the award-winning article in the prestigious journal Organizational Research Methods. Tomaž Cater is the corresponding author and can be contacted at: tomaz.cater@ef.uni-lj.si

Barbara Cater, Ph.D., is a Full Professor of Marketing at the School of Economics and Business, University of Ljubljana, Slovenia. During her doctoral study she spent three months at University of 
Nottingham (UK) and she completed her master study at Drury University (USA). She was a visiting scholar at University of Regensburg (Germany). Her main research interests lie in business-to-business marketing and sustainable issues in marketing. Her articles have been published in several international journals, such as Industrial Marketing Management, Journal of Small Business Management, International Journal of Contemporary Hospitality Management, Journal of Business and Industrial Marketing, Service Industries Journal etc.

Matej Cerne, Ph.D., is an Associate Professor of Management at the School of Economics and Business, University of Ljubljana, Slovenia. His research interests include non-technological innovations, creativity, organizational behavior and psychology, human resource management, leadership, and multi-level issues in management. His research was published in top management journals, including the Academy of Management Journal. He serves as editor-in-chief of the Dynamics Relationships Management Journal, associate editor of Economic and Business Review, and an editorial board member at The Leadership Quarterly, Human Resource Management Review and Human Resource Management Journal.

Matjaž Koman, Ph.D., is an Associate Professor of Economics at the School of Economics and Business, University of Ljubljana, Slovenia. He was visiting researcher at Columbia University (USA) and National University of Singapore. His research focuses on economics of transition and labor economics, with special emphasis on firm behavior and firm's productivity issues. He published a number of articles, among them also in Journal of Comparative Economics and Eastern European Economics. He was also involved in several national and international projects. He teaches microeconomics, managerial economics and mathematics for economists.

Tjaša Redek, Ph.D., is a Full Professor of Economics at the School of Economics and Business, University of Ljubljana, Slovenia. She studied at the University of Ljubljana and at the London School of Economics. Her research focuses on different development and sustainability-related topics, such as intangible capital, new technologies, firm development, competitiveness and sustainable socio-economic development, primarily in the context of labor markets. She published a number of publications and has been involved in several national and international projects. She teaches development economics, competitiveness policy and microeconomics.
Industry 4.0 technologies usage

For instructions on how to order reprints of this article, please visit our website:

www.emeraldgrouppublishing.com/licensing/reprints.htm

Or contact us for further details: permissions@emeraldinsight.com 